
(2-Й ЕТАП НАВЧАННЯ)

\title{
CONTENTS OF THE EDUCATIONAL-CORRECTIONAL METHOD OF FORMATION THE SPATIAL SIGNAL-SYMBOLIC SYSTEM OF KNOWLEDGE IN CHILDREN WITH INTELLECTUAL DISABILITY OF MIDDLE DEGREE (STAGE 2 OF THE TRAINING)
}

Удк 316.6

DOI https://doi.org/10.32843/2663-

5208.2020.12-1.31

\section{Каменщук Т.Д.}

к.пед.н., старший науковий співробітник Український науково-методичний центр практичної психології

і соціальної роботи,

директор

Навчально-методичний центр психологічної служби системи освіти Вінницької області
Стаття присвячена актуальній психолого-педагогічній проблемі фрормування просторової знаково-символічної системи знань у дітей 8-12 років з інтелектуальною недостатністю помірного ступеня шляхом застосування психолого-педагогічних умов, методів і прийомів навчально-корекційного спрямування. У змісті подано перелік основних 4 етапів навчання, зокрема автором детально розкрито 2-й етап навчання маніпулятивний, або предметно-практичний. Виокремлено диреренційовані напрями, зміст, які підпорядковані спільній меті та спрямовані на вирішення конкретних навчально-корекційних завдань. Означено педагогічні умови, методи та прийоми фрормування просторової знаково-символічної системи знань, етапність у їх застосуванні становить цілісну методику, упровадження якої сприяє підвищенню рівня самостійності цих дітей і сприяє їхній соціалізації в предметно-просторовому середовищі. Корекційно-розвивальна робота спрямована на просторове та мовленнєве сприймання, корекцію розумової діяльності шляхом фрормування вміння накладати, прикладати, показувати просторові знаки й символи, орієнтуючись на назву, а також знаходити ix за аналогією. Визначено особливості в структурі корекційного заняття, а саме: корекційна зарядка, зосередження уваги на знаках і символах, практичні вправи з реальними предметами та фротографріями, практичні вправи $з$ малюнками та рисунками знаків і символів, робота зі схемами, робота в предметно-просторовому середовищі (у межах різних кімнат), релаксаційні завдання, робота із зошитом, робота з батьками; підсумок заняття. За результатами експериментального дослідження встановлено ефрективність навчально-корекційної методики (2-й етап навчання) фоормування просторової знаково-символічної системи знань у дітей з інтелектуальною недостатністю помірного ступеня, яка загалом залежить від послідовності в застосуванні методів і прийомів, видів діяльності, індивідуальних уподобань та інтересів цих дітей до різних просторових знаків і символів.
Ключові слова: просторові знаки та символи, діти з інтелектуальною недостатністю помірного ступеня, навчально-корекційна методика, маніпулятивний етап навчання.

The article is devoted to the actual psychological-pedagogical problem of formation of spatial sign-symbolic system of knowledge in children of 8-12 years with moderate intellectual disability by application of psychological-pedagogical conditions, methods and techniques of educational-correction direction. The list contains 4 stages of training, but the author details the second stage of training - manipulative or subject-practical. Differentiated directions, content, which were subordinated to the common purpose and aimed at solving specific educational and correction tasks, were distinguished. The pedagogical conditions, methods and methods of forming the spatial sign-symbolic system of knowledge are defined. Correctional development work was aimed at spatial and speech perception, correction of mental activity by forming the ability to impose, apply, show spatial signs and symbols, focusing on the name, as well as find them by analogy. The features in the structure of correction training are defined, in particular: correction charging, focusing on signs and symbols, practical exercises with real objects and photos, practical exercises with drawings and drawings of signs and symbols, work with diagrams, work in the object-space environment (within different rooms), relaxation tasks, work with a workbook, work with parents; the result of the lesson. According to the results of the experimental study, the effectiveness of the educational and correction methodology (2nd stage of training) of the formation of spatial sign-symbolic system of classes in children with intellectual deficiency of moderate degree, which as a whole depends on the consistency in the application of methods and techniques, activities and individuals these children to different spatial signs and symbols.

Key words: spatial signs and symbols, children with moderate degree of intellectual disability, educational and correction methodology, manipulative stage of learning.
Постановка проблеми. Навчально-корекційна методика формування просторової знаково-символічної системи знань (далі ПЗССЗ) у дітей 8-12 років з інтелектуальною недостатністю помірного ступеня (далі - ІНПС) має на меті цілеспрямований i послідовний вплив на засвоєння просторових знаків і символів, їх практичне використання в різних видах життєдіяльності дітей з ІНПС.

Методика розроблялася 3 урахуванням типової послідовності природного розвитку дитини в онтогенезі та нерівномірності розвитку дитини з IHПC. Ураховано також, що значна частина дітей з IHПC не зможе набути 
певних навичок, характерних для дітей із типовим розвитком.

У загальному вигляді навчально-корекційна методика формування ПЗССЗ у дітей з ІНПС містить 4 етапи: орієнтувально-мотиваційний (І етап), маніпулятивний, або предметно-практичний (II етап), комунікативно-інтеграційний (III етап) і діагностично-оцінювальний (IV етап). Водночас вищезазначені етапи містили диференційовані напрями, зміст, методи та прийоми, які підпорядковані спільній меті та спрямовані на вирішення конкретних навчально-корекційних завдань. Педагогічні умови, методи та прийоми формування ПЗССЗ, етапність у їх застосуванні становить цілісну методику, упровадження якої має підвищити рівень самостійності та сприяє соціалізації цих дітей у предметно-просторовому середовищі [6, с. 147-191].

В основу розробленої навчально-корекційної методики формування ПЗССЗ удітей зІНПС покладено діяльнісний підхід (П. Гальперін) [3]. У процесі навчання ефективно застосовані методи, прийоми, альтернативні загальноприйнятим у дидактиці, які сприяли підвищенню якості пристосування (адаптації) дітей з ІНПС до навколишнього оточення.

Аналіз останніх досліджень і публікацій. Відповідно до психолого-педагогічної концепції особистісно зорієнтованого виховання (І. Бех), на якій базувалася навчально-корекційна програма, весь навчально-виховний і позанавчально-виховний процес спрямований на соціальний розвиток особистості, визнається гуманізм, який тісно пов'язується з вірою в потенційні можливості дитини, спрямований на стимулювання її активності. Ця методика розроблялася з урахуванням положення, згідно з яким процес засвоєння знань відбувається ефективніше, якщо в ньому реалізуються не тільки змістові, а й операційні міжпредметні зв'язки, адже повноцінне засвоєння знань можливе лише в тому випадку, якщо цей процес протікає на основі цілеспрямованого формування операційних структур розумової діяльності (В. Бондар [1], Л. Вавін [4], Л. Виготський [2], І. Єременко [4], В. Липа [8], М. Матвєєва [9], Г. Мерсіянова [4], С. Миронова [10], В. Синьов [12]).

Аналіз науково-методичних джерел, що стосувалися специфіки та шляхів розвитку активності й самостійності дітей у різних видах діяльності (Н. Ветлугіна, 3. Грачова, Н. Сакуліна, К. Тарасова, Б. Теплов, Є. Фльоріна), а також різних аспектів розвитку предметної діяльності дітей: значення, сутність і шляхи іiї формування (Л. Венгер, О. Запорожець, А. Люблінська, О. Леонтьєв, В. Мухіна) дав змогу послідовно виділити етапи навчання та чітко сформулювати мету кожного з них. у наукових дискурсах вітчизняних науковців
(Т.Д. Ілляшенко, А.Г. Обухівська) з'являються акценти на включенні батьків дітей з особливостями в розвитку в навчально-корекційну роботу з їхніми дітьми [6; 13, с. 69-73].

Під час розроблення змістового наповнення навчально-корекційної методики з формування ПЗССЗ у дітей з ІНПС ми опиралися на програми розвитку для дітей з ЛРВ дошкільного віку та для дітей з ПРВ молодшого шкільного віку [11].

Постановка завдання. Мета статті дослідження актуальної психолого-педагогічної проблеми формування просторової знаково-символічної системи знань у дітей 8-12 років з інтелектуальною недостатністю помірного ступеня шляхом застосування психолого-педагогічних умов, методів і прийомів навчально-корекційного спрямування.

Виклад основного матеріалу дослідження. Включення дитини в практичну діяльність з просторовими знаками та символами (далі - ПЗС) відбувається під час 2-го етапу навчання - маніпулятивного, або предметно-практичного, тоді ж передбачається формування вміння впізнавати ПЗС за зображенням в об'ємній і площинній їх проекції (фотографія, рисунок, малюнок), якщо потенційні можливості кращі, то й називати ПЗС.

Корекційно-розвивальна робота спрямована на просторове та мовленнєве сприймання, корекцію розумової діяльності шляхом формування вміння накладати, прикладати, показувати ПЗС, орієнтуючись на назву, знаходити їх за аналогією. На цьому етапі передбачалося продовження виховної роботи, розпочатої на першому етапі, значна увага приділялася вихованню вміння самостійно здійснювати вибір, адекватно реагувати на помилки та виправляти їх. Навчання реалізовувалося за 3 напрямами: предметно-практичним, предметно-ігровим та ігровим дидактичним [7].

Предметно-практична діяльність (практичні маніпуляції - проби та помилки; зорове порівняння) провідна, що включала стискання та хапання, елементарне тактильне обстеження, утримання, кидання, операції переміщення ПЗС (розмахування, штовхання, стискування); обведення, доторкання, обмацування, виконання дій з предметами, упізнавання ПЗС за аналогією та за назвою, накладання, прикладання до зразка, примірювання, розкладання, складання, роз'єднання, з'єднання, нанизування, співвіднесення; ігрову та сюжетно-ігрову діяльність. Для вивчення на цьому етапі пропонуються ПЗС, які вивчалися на попередньому етапі, а також контурні предметні картинки, рисунки ПЗС.

Методи та прийоми підібрані для формування вміння розпізнавати та співвідносити за аналогією ПЗС, знаходити ПЗС у навко- 
лишньому предметно-просторовому середовищі. Першочергово здійснюється виконання завдання за наслідуванням в умовах провідного виду діяльності емоційного спілкування, стимулювання дитини з ІНПС до активності й самостійності в засвоєнні програмового матеріалу.

Розглядаючи методи та прийоми в процесі реалізації практично-маніпулятивного напряму, пріоритетним був метод спонукання до початку дій дитини з ПЗС, що передбачав прийом демонстрації та відтворення соціальних жестів і дій дорослого.

Найбільш продуктивним був метод спільного виконання простих рухів і дій дорослого з дитиною впродовж багаторазового їх повторення, при цьому використовувалися прийоми накладання, прикладання, практичного примірювання; контактного, повторного обведення ПЗС; розрізнення, впізнавання, вибору, співвіднесення, з'єднання, складання, відтворення позицій розміщення ПЗС; розкладання 3 ПЗС за аналогією, за зразком, за жестовою, словесною інструкцією (вибрати щоразу найбільшу/найменшу).

Доцільним виявилося використання методів і прийомів, які підвищують активність дитини з ІНПС із прийомами наслідування дій дорослого за жестовою інструкцією; показу з опорою на зразок і в поєднанні з коментуванням дій дорослим, а також погладжування по голові, руці, доторкання, легке лоскотання, притискання дитини в руках дорослого, спільне покачування, прийоми масажу (погладжування, розтирання, розминання, вібрація, похитування, пощипування, натискання або легке стискання).

Значну роль у стимулюванні активності дитини з ІНПС відігравав метод показу різноманітних за кольором, формою, величиною ПЗС із застосуванням прийому тривалого їх розглядання та метод демонстрації об'ємних ПЗС із прийомом показу вказівного жесту, дослідження вказівним пальцем об'ємної ПЗС, проведення пальцем від предметної ситуації до ПЗС і, навпаки, поелементної демонстрації жестів і дій з ПЗС.

Наступним є метод обстеження, який супроводжувався такими прийомами: «рука в руку» (вкладання в руку дитини ПЗС), обмацування, обертання, перекладання, струшування, кидання, прийом вимірювання пальцями або руками ПЗС, прийом порівняння величини ПЗС шляхом накладання чи прикладання, а також підтримуючі та направляючі прийоми.

Під час оволодіння новими діями ефективними були практичні методи: метод проб і помилок і метод пасивних рухів. Це ті методи, які найменше потребують будь-якого досвіду дитини та високого рівня розвитку орієнтовно-практичної діяльності, їх застосування допомагають фіксувати позитивні дії, а проби формують цілеспрямовані дії. Метод наслідувальних вправ містив прийом багаторазового повторення дитиною дій (розумових чи практичних) з ПЗС і прийом тренувальних вправ.

Методи практичної діяльності також реалізовувалися через прийоми відтворення аплікації, штрихування, обведення, малювання за трафаретом, замальовування (поперечне, повздовжне), конструювання, порівняння та диференціації, підбору ПЗС за типом звучання, визначення місця розташування ПЗС, виокремлення, групування, називання, повторення, розкладання, визначення послідовності й чергування, озвучення, використання в ігровій діяльності ППС як сигналу до дії, комбінування, добирання, орієнтування, відображення, порівняння, прийом виділення, зміни активних контактних і неконтактних позицій дитини та дорослого.

Предметно-ігровий напрям передбачав метод виконання простих предметно-ігрових дій: прийом виокремлення об'ємних ПЗС за формою, за кольором, із загального фону, прийом знаходження в знайомому просторі відповідних ПЗС, лото з використанням ПЗС. Ігрові методи містили прийоми введення елементів змагання, прийом створення ігрових ситуацій (спонтанних, запланованих).

Метод безсюжетних рухових ігор передбачав прийом коротких перебіжок поміж ПЗС. Пізнавальна гра реалізовувалася через прийом визначення нового щодо вже до засвоєних ПЗС. Відображувальна гра - прийом відтворення ігрових дій у певній послідовності. Метод фішок: прийом підбору ПЗС до відповідних ПЗС іншого рівня складності. Прийом збільшення на картці зображення ПЗС, поступове зменшення розміру їх зображення.

Метод називання - прийом словесного повторення назв ПЗС, прийом пригадування назв із невербальною/вербальною підказкою, прийом самостійного пригадування назв ПЗС за показом ПЗС.

Ігровий дидактичний напрям містив використання методу піктограм з прийомам відтворення низки заданих ПЗС, а також сюжетно-відображувальну гру.

Розвиток у дітей з ІНПС зорово-рухової координації дрібної моторики реалізовувався за допомогою організації дидактичної гри (настільно-друкована), наприклад, парні ПЗС, лото з графічним зображенням ПЗС, доміно з прийомами короткотривалого залучення до спільних дій.

Застосування мовленнєвої гри на цьому етапі навчання передбачало активізацію уваги дитини до власного мовлення, переважно ознайомчий характер.

Метод проективного обмальовування передбачав прийом малювання по крапках із зображенням ПЗС, за їх контуром. 
Під час розроблення корекційних занять для 2-го етапу навчання враховано, що успішному розвитку дитини сприяє предметна, ігрова та продуктивна діяльність, в умовах якої можлива як перевірка власного досвіду, так і виконання дій дитиною, а також практичне використання засвоєних умінь і знань, моделювання практичних ситуацій, активна взаємодія з дітьми. Тому корекційні заняття 2 етапу пропонувалися для проведення в мікрогрупі (за участю 3 дітей), упродовж яких передбачалося спостереження за власними діями дитини й участю дорослого згідно з ними. На кожному занятті бралося до уваги те, що розвиток дитини з ІНПС відбувається поступово під час здійснення системного цілеспрямованого навчання, налагодженого спілкування з дорослим і дітьми, підтримкою активності в діяльності. у процесі розроблення структури кожного заняття нами враховані конструктивні принципи використання робочого матеріалу: зліва направо, від простого до складного тощо.

Корекційні заняття 2-го етапу навчання мали свої особливості в структурі, а саме: корекційна зарядка, зосередження уваги на знаках і символах, практичні вправи з реальними предметами та фотографіями, практичні вправи з малюнками та рисунками знаків і символів, робота зі схемами, робота в предметно-просторовому середовищі (у межах різних кімнат), релаксаційні завдання, робота із зошитом, робота з батьками; підсумок заняття.

Корекційна зарядка під час організаційного моменту була спрямована на активізацію позитивних емоцій і формування емоційно-позитивного ставлення до спільної роботи з дорослим та дітьми. Вправи для зосередження уваги на ПЗС передбачали активізацію пізнавального інтересу дитини до тих ПЗС, які будуть вивчатися на занятті, їх місця знаходження та практичного застосуванні.

Завдання основної частини заняття добиралися 3 урахуванням його цілеспрямованості, розраховані на організацію активної пізнавальної та практичної діяльності дитини з ПЗС. Демонстрація дорослим способів дій з ПЗС із вербальним підкріпленням передбачала формування пошукових способів орієнтування (проби, примірювання), способів обстеження (обмацування та проведення пальцем, дослідження рукою, двома руками або по черзі), проведення олівцем по контуру ПЗС, розглядання, виділення із загального простору знайомого ПЗС, вибір (одного з двох ПЗС однієї групи, двох однакових з ряду інших до 5 картинок, такого ж ПЗС серед багатьох інших (від 5 картинок) рукою, поглядом); вимірювання пальцем довжини; вкладання, обертання, перекладання, струшування, кидання, з'єднання, роз'єднання, розкладання, складання, перекладання, гру- пування, співвідношення ПЗС під час вирішення практичних або ігрових завдань.

Основна частина ґрунтувалася на застосуванні практичних прав. Практичні вправи з реальними предметами та фотографіями передбачали зосередження уваги на руках дитини й кінці вказівного пальця, формуванні вказівного жесту на означений знак і символ, зосередженні уваги на реальних предметах і фотографіях, їх обстеженні та виокремленні в предметно-просторовому середовищі.

Практичні вправи з малюнками та рисунками знаків і символів спрямовані на формування зацікавленості до них загалом, зорового впізнавання, їх розрізнення, а також на формування співвідношення реальних предметів з їх площинними зображеннями, акустичні зосередження на звуках, активізації тактильнокінестетичних відчуттів.

Робота зі схемами на робочому місці й у предметно-просторовому середовищі націлена на складання динамічного ланцюжка знаків і символів за допомогою дорослого, місцезнаходження знака та символу в предметно-просторовому середовищі. Релаксаційні завдання спрямовані на закріплення уявного способу дій з ПЗС, зосередження на власних відчуттях із заплющеними очима.

Робота із зошитом передбачала перенесення засвоєних знань дитини в площинну робочого зошита та формування нових практичних умінь з ПЗС (порівняння, накладання, підкладання, практичного примірювання, групування, складання, контактного повторного обведення, малювання: штрихування, малювання за трафаретом, замальовування, аплікацію).

Важливим структурним компонентом заняття була робота з батьками, яка передбачала демонстрацію виконаних дитиною завдань, залучення батьків до спільного виконання тих завдань, які дитина не в змозі виконати самостійно. Вдалим доповненням були такі види роботи, як конструювання та ліплення.

Підсумкова частина передбачала фіксацію ступеня досягнення мети й формування мети наступного заняття. Поетапність засвоєння будь-якої практичної дії з ПЗС передбачала збільшення активності дитини з ІНПС у визначеній діяльності. Після кожного спільного виконання дій дитині пропонувалося виконати завдання повторно, з більшою самостійністю. В ігрових завданнях і дидактичних іграх дорослий, стимулюючи активність дитини, діяв не випереджаючи ії ініціативу.

Висновки 3 проведеного дослідження. Отже, основу навчально-корекційної методики формування просторової знаково-символічної системи знань дітьми з інтелектуальною недостатністю помірного ступеня в процесі цілеспрямованого системного навчання ста- 
новлять уміло поєднанні психолого-педагогічні умови, структуровані напрями та зміст навчальних методів, прийомів і завдань, а ефективність цього навчання залежить від послідовності в їх застосуванні, видів діяльності, індивідуальних вподобань та інтересів цих дітей до різних просторових знаків і символів.

\section{ЛІТЕРАТУРА:}

1. Бондар B.І. Історія олігофренопедагогіки. Київ : Знання, 2007. 376 с.

2. Выготский Л.С. Собрание сочинений : в 6 т. / под ред. А.Р. Лурия, М.Г. Ярошевского. Москва : Педагогика, 1982. Т. 1 : Вопросы теории и истории психологии. 488 с.

3. Гальперин П.Я. Опыт изучения формирования умственных действий. Вестник Московского университета. Серия 14 «Психология». 2017. № 4. C. 3-20.

4. Єременко І.Г., Вавіна Л.С., Мерсіянова Г.М. Диференційоване навчання у допоміжній школі. Київ, 1979. С. 14.

5. Восприятие и действие / А.В. Запорожец, Л.А. Венгер, В.П. Зинченко, А.Г. Рузская. Москва, 1967. 323 c.

6. Інноваційні технології в діяльності інклюзивноресурсного центру : методичний посібник / авт. кол за ред. А.Г.Обухівська, Т.Д. Ілляшенко. Київ : Український НМЦ практичної психології і соціальної роботи, 2019. 228 c.

7. Каменщук Т.Д. Просторова знаково-символічна система знань як феномен психічного роз- витку особистості. SCIENCE FOR SUSTAINABLE DEVELOPMENT : матеріали Міжнародного конгресу I за заг. ред. профр. О.В. Кендюхова. Київ, 2019. 416 с.

8. Липа В.А. Коррекционые цели в специальном обучении : монография. Славянск : Изд-во Б.И. Маторина, 2016. 283 с.

9. Матвєєва М.П. Корекційна робота в системі освіти дітей з вадами розумового розвитку : навчально-методичний посібник. Кам'янець-Подільський:Кам'янець-Подільськийдержавнийуніверситет, 2005. 164 c.

10. Миронова С.П. Методика корекційної роботи при порушеннях пізнавальної діяльності : підручник. Кам'янець-Подільський : Кам'янець-Подільський національний університет імені Івана Огієнка, 2014. 260 c.

11. Особливості психолого-педагогічного супроводу дітей 3 помірною розумовою відсталістю в системі корекційно-розвивального навчання спеціального загальноосвітнього закладу : навчальнометодичний посібник / за наук. ред. О.В.Чеботарьової, І.В. Гладченко. Київ : ІСП НАПН України, 2016. $148 \mathrm{C}$.

12. Синьов В.М. Корекційна психопедагогіка. Олігофренопедагогіка : у 2 ч. Київ : НПУ ім. М.П. Драгоманова, 2007. Ч. 1. 241 с. ; Ч. 2. 223 с.

13. Соціально-реабілітаційні і навчальні програми в роботі інклюзивно-ресурсного центру із сім'єю : методичний посібник / Т.В. Жук, О.Г. Задорожня, А.В. Замша, Т.Д. Ілляшенко, Т.М. Костенко, А.Г. Обухівська, Г.В. Якимчук ; за ред. А.Г. Обухівська. Київ : Український НМЦ практичної психології і соціальної роботи, 2018. 208 с. С. 69. 